\title{
Determinants of Income Diversification among Rural Farm Household in Soddo District, Gurage Zone of Southern Ethiopia
}

\author{
MESFIN HAILU TEJI \\ Alage Atvet College \\ Osman Oumer Esmail, Ethiopia Biotechnology Instiute, Po Box 5954, Addis Ababa, Ethiopia
}

\begin{abstract}
Soddo Woreda is one of the major producers of agricultural product in Gurage zone but, it lacks well-organized and arranged marketing system that highly affects fair distribution of income diversification. The overall objective of this study was to analyze the determinants of income diversification rural farm households in Soddo Woreda. This paper examines the determinants of income diversification among rural households using cross sectional data collected through a multi-stage random sampling technique and selected 200 sample from farm households of Soddo District of Gurage Zone, southern Ethiopia. Both descriptive statistics and rigorous econometric models are used to analyze the data. Multinomial logit model was used to analyze factors influencing households' participation in off/non-farm income activities. The Herfindahl-Hirschman Index (HHI), shows that agricultural activities are the most important and basic source of income for rural households in Soddo District contributing crop income $58.16 \%$ and livestock income $28.49 \%$ summing up farm income $86.7 \%$ of total household income with the remaining $13.3 \%$ originating from off-farm $3.7 \%$ and non-farm $9.6 \%$ income activities. About $74 \%$ of the sample households involved in off/non-farm income activities and $26 \%$ involves in farm income only. The involvement in off/non-farm employment activities and the level of income derived are found to be influenced by human capital related variables (gender and age of household head, number of family m embers, education level of household head, attitude to risk and ), livelihood assets (livestock holding, size of cultivated land, irrigated land, wealth of households, aggregate total crop product) and infrastructure related variable (proximity to market, extension service, access to credit and cooperative). The results imply that these factors need to be considered by policy makers in the planning of agricultural and off/non-farm initiatives in this study area.
\end{abstract}

Keywords: Income diversification, Herfindahl-Hirschman Index (HHI).

DOI: $10.7176 / \mathrm{DCS} / 10-10-02$

Publication date:October $31^{\text {st }} 2020$

\section{Background the study}

Agriculture remains the main source of income for the majority of the rural population of developing countries. Nevertheless, a large proportion of rural households modify their economic activities in a variety of ways under different conditions (Ellis, 2000). Firstly, farm households may intensify extensity or diversify their agricultural production. Secondly, they may also diversify their portfolio of economic activities outside agriculture either on or outside of the farm, or some members might migrate to other areas temporarily or permanently in search of better opportunities. In this study diversification refers to a process in which households voluntarily or involuntarily increase the number of economic activities they are involved in. Thus, we can say diversification is the norm. Diversification is defined as the process by which rural households construct increasingly diverse livelihood portfolios, making use of increasingly diverse combinations of resources and assets in order to meet their basic needs, improve their living standards or welfare, and manage risk (Niehof, A., 2004). Non-farm \& offfarm income generating activities provide an important source of primary employment in the rural areas of most developing countries', and it is assumed that as farm size due to population pressure becomes smaller, the percentage of non-farm income becomes larger (Hilson, 2016).

The main question and concerns of policy makers is to make sure whether or not it is possible to support farmers to engage in off/non-farm activities without sacrificing the farm productivity and food self-sufficiency objectives. Hence, looking into the link between farm and non/off-farm activities is necessary before policy measures are taken to promote non/off-farm activities (Tassew, 2000, Amare D., 2013).

Income diversification is the norm in rural societies, and specialization in a single activity is the exception (Dimova and Sen, 2010). It is argued that diversification smoothes the flow of household income, by diversifying risks. As Ellis (1998) and Maitra (2001) states, this is often necessary in agriculture based peasant economies because of numerous risks such as variability in soil quality, crop diseases, price shocks, unpredictable rainfall and other weather related events which lead to low income and continually trap them in a vicious cycle of poverty.

In recent years after $2010^{\text {th }}$, there is good increasing recognition of the importance of income diversification for rural household in our country, Ethiopia. Considering the dominance of the agrarian economy, ADLI (Agricultural Development Led Industrialization), the government's principal strategy for sustainable economic growth, focuses on the development of the rural sector. An important aspect of ADLI is to promote the rural nonfarm sector and enable it to interact with agriculture. According Bassie Y.,(2014), farm households in rural areas 
participate in multiple economic activities and thus diversify income sources to minimize agriculture related risks and problems. In view of this, nonfarm and off farm activities have recently become one of the main income diversification strategies widely practiced by most farmers in developing countries.

\section{Statement of the Problem}

Agriculture is considered as a strong option and fundamental instrument for spurring growth and sustainable development, poverty reduction, and enhancing food security in developing countries like Ethiopia.

Different literature (Berhanu, 2006, Mulat, 2001 ;Bassie Yizengaw ,2014; Yishak Gecho, 2017 ) show clearly that poverty occurrence in Ethiopia is higher among the rural-people, that is, households that rely mainly on agricultural income and those with low paid work in the rural off/non-farm sector. This may be connected with the low productivity growths that have characterized Ethiopian agriculture over the periods. In Ethiopia, the rate of poverty reduction achieved from various poverty reduction strategies adopted is far below what was required to achieve the poverty reduction goal of Millennium Development Goals (MDG). Involvement in the non-farm activities increases the income source which results in income growth and mitigates income variability among rural farm households.

According to studies such as Woldenhanna and Oskam ( 2001); Holden, Shiferaw and Pender, (2004); Yisihake Ergicho and Abebe M.(2015); Yishak Gecho (2017), focus on identifying determinants of income diversification, off/non-farm activities, household participation in off-farm employment only by focusing specific part of country. Moreover, policy makers and others did not look at the way in which the rural income diversification is integrated with employment opportunities, natural resource management and other poverty reduction strategies due to the lack of empirical evidences that help to understand well the variables which motivates rural income diversification. Even though the district proxy to the capital town of the zone and infrastructure (asphalt road) in the study area are mostly based on farming and income diversification were not widely practiced. This shows that there is a gap in rural households to diversify their income sources to spread risk in the study area (MoFED, 2002).

Despite of a vast potential for off/non-farm activities in the study area, there are problems such as negative perception of the community, out-dated methods of production, lack of improved technology and skill, and lack of business start-up budget. There is also no research conducted in the area in this regard to study the effect of off/non-farm activities on farm production and to identify the major problems that hamper the off/non-farm sector. Thus, a good assessment of the determinants of income diversification, decision to involvement in off/non-farm activities in rural farm households are essential to fill this gap and for the designing policies promoting alternative income.

\section{Objectives of the Study}

3.1 General Objective

The general objective of this study was to analyze the determinants of income diversification of households (HHs) involvement in off-farm/non-farm activities in rural farm households in Soddo District, Gurage Zone.

\subsection{Specific Objectives of the Study}

This study would try to achieve the following specific objectives:

$\checkmark$ To assess status of income diversification among farm households in the study

$\checkmark$ To analyze determinants of farm households (HHs) income diversification into off-farm/ and non-farm activities in the study area.

\section{Literature Review}

\subsection{Empirical Literature Reviews}

\subsubsection{Determinants of Household Income Diversification}

In a study that examines the relationship between income diversification and its effect in Ethiopia, Bassie Y., (2014) found that households living in rural areas with highly variable rainfall were more likely to have a large number of income sources, which was consistent with the idea of income diversity serving as a risk management strategy. In addition Amare D., (2013) Income Diversification is considered as the most important strategy for raising income and risk minimizing in Eastern hararghe zone. His study concluded in 2009 depicts that activities outside of the agricultural sector play an important role in this study area contributing about $23 \%$ of the total household income.

According to the study Yishak G., (2017), it is increasingly becoming clear that the agricultural sector alone cannot be relied upon as the main activity for rural households as a means of improving livelihood, achieving food security and reducing poverty in Wolaita Zone,. Income diversification is gaining prominent role in rural households' income and food security. Even though, regarding the rural economy in Ethiopia, policy makers give more attention to agricultural sector. 
Damite (2006) analyzes the determinant and the impact of income diversification in Ethiopia the case communities in southern nation, nationalities peoples of the regional state. It was use Multinomial logit model to analyses the determinants of household's level of income diversity that corrects selection bias estimated for five distinct livelihood strategies. The effects of income diversification on rural equity and consumption insurance against idiosyncratic income shock were analyzed using Gini decomposition technique and linear regression model, respectively.

Lemi- (2006) analyzed the dynamics of income diversification in Ethiopia by using 1994 and 1997 ERHS panel data. The results show that participation in off-farm activities is mainly driven by demographic factors, whereas land and other asset ownership as well as crop production and income affect intensity of off-farm activities 4.1.2 Importance's of Income Diversification on livelihood improvement

According to the researcher (Bassie Y., 2014) income diversification were found to be important for farm households to serve as additional source of income and complementing the income earned from agriculture and serve as a great contributor to household food security restricting their probability of selling of food grains and cover the extra household expenses. Income diversification affects consumption stability and the overall welfare of households. The determinants of income diversification in the study area were education, household size, credit and extension contact. These variables were positively related to income diversification. Promising routes out of extreme food insecurity include adding enterprises to a farm, or diversifying into non-farm or wage employment. (Zeraia and Gebreegziabher, 2011) studied on the effect of non-farm income on food security by using Hickman two stage methodologies in eastern Tigray region. The result indicates that non-farm employment provides additional income that enables farmers to spend more on their basic needs include food, education, closing and health care. This implies that that non-farm employment has a significant in maintaining household food security.

\section{Research Methodology \\ 5.1 Research Design}

This research was been conduct with both empirical and by employing descriptive method of research because descriptive research is fact finding and describes the current condition of phenomena. Due to the complexity of the issue the research was conducted by employing both qualitative and quantitative research approaches to get descriptive and relevant information about the issue. Using both qualitative and quantitative methods are important to analyze the data in different manner and to minimize the weaknesses of each of the approaches. For this study, both qualitative and quantitative (Mixed) research approaches were used.

\subsection{Types and Source of data}

Both primary and secondary data sources were used. Primary data which includes both qualitative and quantitative data on household socio economic characteristics were obtained through proportional sampling from four rural kebeles total survey of 200 farming households (HHs) in Soddo District, Gurage Zone. The main instruments of data collection with semi-structured questionnaires and interview administered to mainly farming households in the study area. Secondary data was gathered from various sources like Agricultural Development Offices of the Districts, Zone Bureau of Agriculture and Rural Development Office annual report, Books, from different publications, internet websites, articles, Journals and the like.

\subsection{Method of data Collection}

Before actual data collection undertaken, a pre-testing questionnaire was conducted for $20(10 \%$ of samples) households and to four DA's in order to revise and adjust those questionnaires that couldn't provide the required answers. Next to that, the required data was collect through farm household survey using revised structured questionnaire. The interview was conduct by development agent and enumerators who are train on the subject matter of the questionnaire and key information discussion survey was carried out appropriately.

\subsection{Sampling techniques and sample size determination}

In this study a multi-stage sampling techniques was employed to select farm households. In the first stage, by employing purposive sampling method Soddo Woreda has been selected because it is the one which represents a rural settlement where farming is the primary occupation, geographically proxy to the administrative town and main asphalt road of A.A to Butajira town of Gurage Zone and suitable market infrastructure. In the second stage the rural kebeles of Soddo Woreda stratified into three strata based on agro-ecologies namely highland, moderate and lowland. The strata consist of 15 high land kebeles, 26 medium land kebeles and 13 low land kebeles. (Gimise from highland, Buee zuria and Negesa from moderate and Gembela from lowland) with sum total of 1397 household in four kebeles and proportional random sampling techniques from each and data have been collected from the total of 4 selected kebeles.

Different methods were having been suggested for determining the minimum number of subjects required to conduct multiple regression analyses. These rules-of-thumb are evaluated by comparing their results against those 
based on power analyses for tests of hypotheses of multiple and partial correlations (Green, 1991). Accordingly, in this study because of using proportional random sample size selection, it was preferable to sample based on the rule of thumb $\mathrm{N} \geq 50+8 \mathrm{~m}$, where, $\mathrm{N}$, is sample size and ' $\mathrm{m}$ ' is the number of explanatory variables (Xi) where $\mathrm{i}=1,2 \ldots 18$. Based on thumb rule the research was select four kebeles randomly from 54 rural kebeles of the district and take a total sample of 200 respondents from the selected district. This can be described briefly in table below. Table.5.1. Sample determination on each kebeles

\begin{tabular}{|l|l|l|}
\hline Kebeles & No of household & Sample size \\
\hline Buee zuria & 376 & 54 \\
\hline Gembela & 400 & 57 \\
\hline Gimise & 341 & 49 \\
\hline Negesa & 280 & 40 \\
\hline Total & 1397 & $\mathbf{2 0 0}$ \\
\hline
\end{tabular}

Source:-Soddo Woreda agricultural and natural resource development office report 2018/19.

\subsection{Data Analysis Techniques}

\subsubsection{Descriptive analysis}

Before econometric analysis, descriptive analysis was used to explain and interpret the data obtained from household survey of the study. The result of the questionnaire survey was analyzed by the help of statistical package for social sciences, STATA-13 Statistical Software and Microsoft excels 2007 after editing, coding and arranging the raw data collected from survey.

\subsubsection{Econometric Analysis}

An econometric model consists of a dependent variable, also called the left-hand-side variable, and independent variable(s), also called explanatory or right-hand-side variable(s) and an error terms, or to be more precise stochastic disturbance terms, which stand for unobservable random variables not explicitly included in the model. The error term may also reflect randomness in human behaviour or measurement errors, and has certain assumed properties such as a mean, variance and covariance. The estimated coefficients indicate the effect of a change in the independent variables on the dependent variable (Green, 2003).

Multinomial Logistic Regression Model:- When there is a dependent variable with more than two alternatives among which the decision maker has to choose (i.e. unordered qualitative or polychromous variables), the appropriate econometric model would be either multinomial logit or multinomial probit regression model. multinomial logit model is selected not only because of the computational ease but also multinomial logit analysis exhibits a superior ability to predict income diversification and picking up the differences between the diversification strategies of rural households. It is a simple extension of the binary choice model and is the most frequently used model for nominal outcomes that are often used when a dependent variable has more than two choices.

In this study therefore, to examine the determinants of number of income diversification sources among farming households multinomial Logistic regression analysis was used. The significance of an individual coefficient can be tested using the t-test of significance and the joint significance of two or more coefficients using the F-test (Gujarati, 1998).

The general form of the model was: $\mathrm{Y}=\mathrm{XiBi}+\mathrm{Ui}$

Where: - Y is income diversification sources (dummy), Xi explanatory variables, Bi coefficients of explanatory variables and $\mathrm{Ui}$ : is normally distributed with zero mean and constant variance. Consider the outcomes $1,2,3,4$. . M recorded in $y$, and the explanatory variables X. There are $\mathrm{m}=4$ outcomes: "on farm only", "offfarm", "non-farm", and "mixed of off-farm and non-farm". The values of y are then said to be "unordered". Even though the outcomes are coded $1,2,3$, and 4 , the numerical values are arbitrary because $1<2<3<4$ does not imply that outcome 1 is less than outcome 2 is less than outcome 3 is less than outcome 4 .In the multinomial logit model, you estimate a set of coefficients, $\beta(1), \beta(2), \beta(3)$, and $\beta$ (4), corresponding to each outcome:

$$
\begin{aligned}
& \operatorname{Pr}(\mathrm{y}=1)=\frac{\mathrm{e}(\mathrm{X} \beta)^{1}}{\operatorname{eX} \beta(1)+\operatorname{eX} \beta(2)+\operatorname{eX} \beta(3)+\operatorname{eX} \beta(4)} \\
& \operatorname{Pr}(\mathrm{y}=2)=\frac{\mathrm{e}(\mathrm{X} \beta)^{2}}{\operatorname{eX} \beta(1)+\operatorname{eX} \beta(2)+\operatorname{eXX} \beta(3)+\operatorname{eX} \beta(4)} \\
& \operatorname{Pr}(\mathrm{y}=3)=\frac{\mathrm{e}(\mathrm{X} \beta)^{3}}{\operatorname{eX} \beta(1)+\operatorname{eX} \beta(2)+\operatorname{eX} \beta(3)+\operatorname{eX} \beta(4)} \\
& \operatorname{Pr}(\mathrm{y}=4)=\frac{\mathrm{e}(\mathrm{X} \beta)^{4}}{\operatorname{eX} \beta(1)+\operatorname{eX} \beta(2)+\operatorname{eX} \beta(3)+\operatorname{eX} \beta(4)}
\end{aligned}
$$

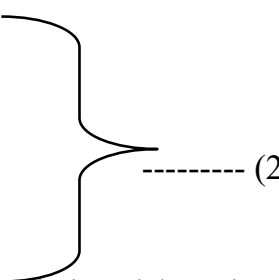

Thus the exponentiated value of a coefficient is the relative-risk ratio for a one-unit change in the corresponding variable (risk is measured as the risk of the outcome relative to the base outcome) (Hosmer et al., 2013). 


\subsection{Herfindahl Index Hypothesis Measures}

The Herfindahl Index also called Herfindahl-Hirschman Index (HHI), takes into account a number of factors that give analysts and experts a better, more comprehensive view of the health of a specific income. When that income is populated by a lot of big companies, all of them relatively the same size, the index will be at or near zero, low concentration. On the other hand, if a specific income is dominated by a single income source, the index will be dramatically bigger. But in our context there are aggregated crop production and livestock production income sources on the farm, wage employment income (agricultural and non agricultural wages) in the off-farm, and other self employment (selling local bears, food, fire wood and small trading) in non-farm with different share of income. It can be calculated with the formula:-

$H H I=c p^{2}+l p^{2}+w e^{2}+s e^{2} \ldots \ldots \ldots \ldots+m^{2}$. Where :- cp-aggregate crop production, lp- aggregate livestock production, we- wage employment income(agricultural and non-agricultural), se-other self-employment incomes( selling; local bears, foods, fire woods and other small trading) and m-other numbers of incomes like NonLabor income, remittance, transfer, gifts and the likes.

The index is inversely proportionate to the number of income sources in that market. It's also inversely proportionate to the difference in size between those companies.

This means that the closer a market is a true monopoly, the larger that firm's income share would be. For example, let's assume a farm only has a single viable source, active in that farm income; its share will be 100 percent. As a result, its HHI would be 10,000 highly concentrated (Hosmer et al., 2013).

\subsection{Econometric Model testing}

\subsubsection{Model specification tests}

There are econometric testing in multivariate regression model like multicolinearity, autocorrelation, normality test, heteroskedasticity, misspecification, T-test, p-value and f-test. Before proceeding to estimate the data using logit model, checking the existence of multicolinearity between explanatory variables tests was undertaken. The Variance Inflation Factor (VIF) technique was employed to detect the problem of multicolinearity for the continuous variables VIF can be defined as;

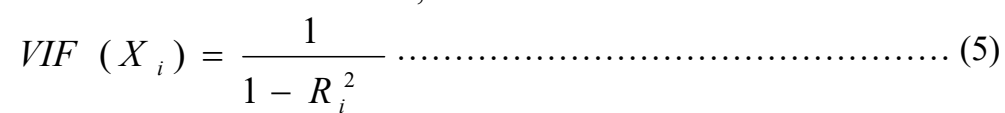

Where $R_{j}$ is the squared multiple correlation coefficient between and other explanatory $\mathrm{X}_{\mathrm{i}}$ variables. The larger the value of VIF, the more troublesome it is. As a rule of thumb if a VIF of a variable exceeds 10 , which will happen if $R_{j}$ (explained variation) exceeds 0.90 , then, that variable is said to be highly collinear. Therefore, for this study, variance inflation factor (VIF) has been used to detect multi-collinearity problem for continuous variables the mean value equal to 3.93 which is less than 10 , multi-collinearity of discrete/categorical variables can be tested with contingency ratio (see appendix table-1). Multi-collinearity continuous variables can also be tested through Tolerance. Tolerance is $1\left(\mathrm{R}_{\mathrm{j}}=0\right)$ if $\mathrm{X}_{\mathrm{i}}$ is not correlated with the other explanatory variable, whereas if it is zero $\left(R_{j=1}\right)$ it is perfectly related to other explanatory variables. Tolerance can be calculated as the reciprocal of VIF.

The study was test multinomial logit it is very important to test independence of irrelevant alternatives (IIA) (Greene, 2003). This assumption states that the choice of or membership in one category is not related to the choice or membership of another category (i.e., the dependent variable). The assumption of independence can be tested with the Hausman-McFadden test.

\section{Results and Discussion}

\subsection{Econometric Estimation Result}

\subsubsection{Determinants of Household's Income Diversification}

Income diversification in this study refers to the number of income sources. This is examined in the level of income diversification with Herfindahl-Hirschman Index (HHI) as a measure and dependent variable in rural farm households. Herfindahl Diversification Index are continuous variables but with limited range between zero and 1 (see table-10 above). In this study there are four major income sources, aggregate crop production income with largest share $(58.16 \%)$, aggregate livestock production income with the second share $(28.49 \%)$ in on-farm, nonfarm/self employment income the third share (9.6\%) and off-farm/wage employment income with lowest share (3.7\%) outside of the farm. This mean there is good involvement on off/non-farm with high concentration with base outcomes of on-farm incomes namely aggregate crop income and aggregate livestock incomes.

Sex, education, attitude to risk of diversifying income, cultivated land size, family size, willingness to participate on income diversification/off or non-farm, number of contact by DA's, distance of farm households from main road, credit service and input/output market of household head, participation:, in cooperative, irrigation use, livestock holding and wealth of households significantly affected involvement into off-farm/wage employment activities. Whereas diversification in non-farm/ self employment was significantly influenced by age, 
education of household head, attitude to risk of diversification, cultivated land size, family size, number of contact by DA's, willingness to participate on income diversification/off or non-farm, distance to main road and distance to market, credit service, wealth, number quintal of crops grown and harvested in a season and livestock holding. Similarly, all the variable have significantly influenced involvement in multiple/mixed of off-farm and non-farm employment activities. The standard errors, the z-values and the confidence interval of each outcome are put in appendix table in the detailed manner for multinomial logit regression result is taken as the following table- 2 for each with corresponding coefficient and p-values for sake of relationship and significances levels.

Table-2. Multinomial logit regression estimations for off/non-farm and mixed income choices (involvement). Mlogit offinc, nonfinc, bothinc age sex edu attrisk fexp fsize lsize tlu irruse coop crdtser poffnon nocont distmr distcrt distmrk wealth totalcp, baseoutcome (0) vce (robust)

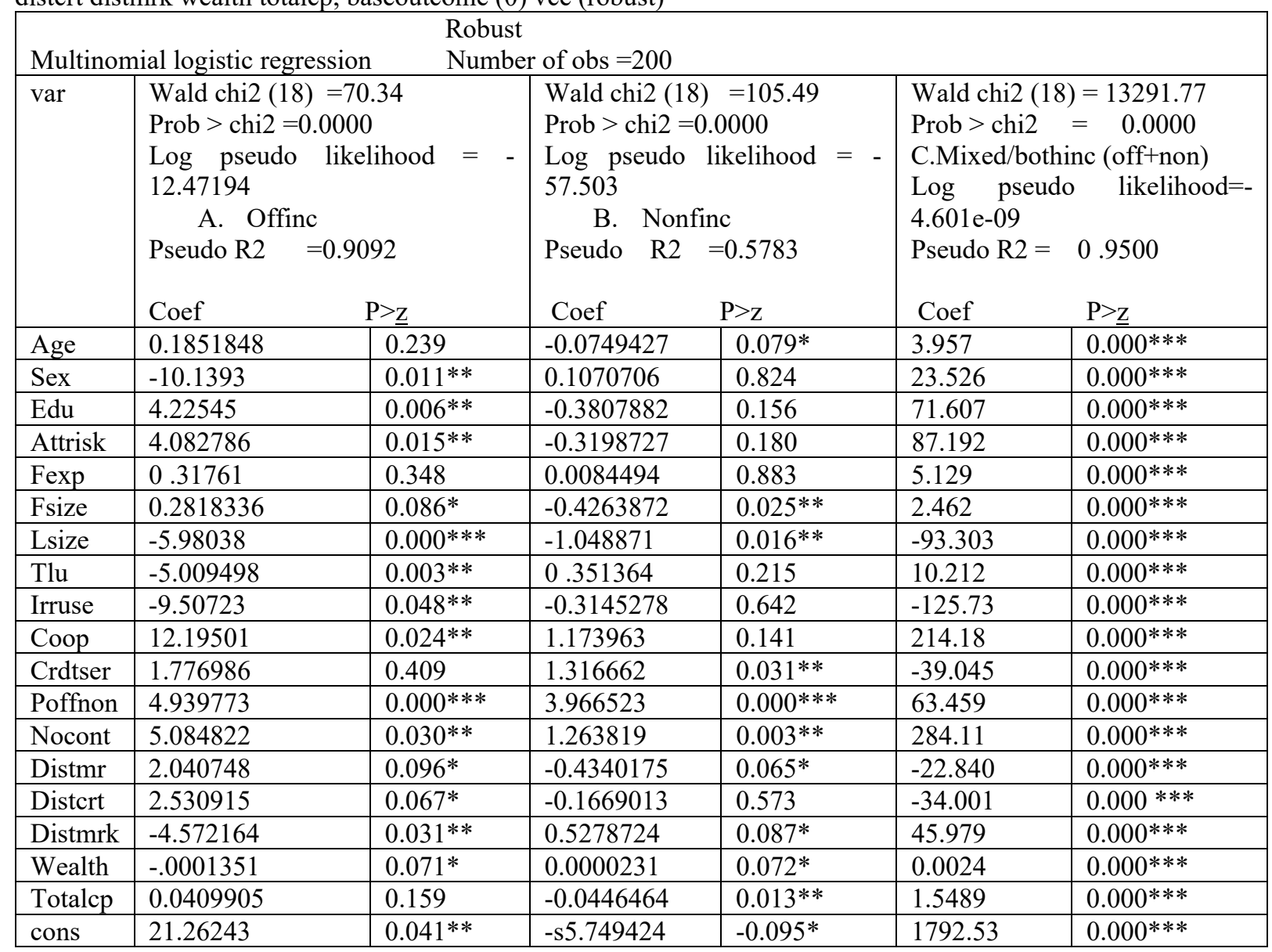

Source: Own survey result (2019)

Moreover, even if the relationship is statistically insignificant, households with higher farm experience are more likely to participate in local off/non-farm activities than their counterpart, as can be seen from the estimation results. As predicted by economic theory, land size and local off farm diversification are negatively related. This implies that, it is more probable for households with larger land sizes to stay on farm as more land sizes stimulates farming. This supports the view that off/non-farm and on-farm activities compete over the limited household resources. It also implies that those households who expect secured agricultural income stay on farm and lower off-farm activities. Lanjouw (1995) also found out that landholdings per capita are negatively correlated with involvement in local off/non-farm activities. As expected, credit use is found to have statistically significant and positive impact on the probability of involving in non- farm activities and negative effects on the likelihood of diversifying in off-farm and engaging only in agriculture. This more implies that the formal and informal credit facilities that avail for rural farmers are a very important asset in rural livelihoods diversification. The result of the study, therefore, strongly suggest that farmers' access and use of credit would play important role in promoting rural income diversification than agricultural production.

As shown in Table 2, credit uses decreases household's participation on agricultural production and this may be due to the risk averse behaviours of our rural farm households. As agriculture is a risky business, rural households would not use credit for investment in agriculture and rather they use for less risky local non-farm activities. This result is in agreement with the finding of Raju (2014).

The age of household head has significantly and negatively affected participation in self employment and 
multiple self-wage employment activities at 10 and $1 \%$ levels of significance, respectively (Table-12). This implies that supply of labor to self and combined off/ non -farm employment activities was higher for younger households than older households. Hence, younger households rely on non/off-farm employment to support their livelihoods while the older ones concentrate on farming instead of opting for engagement in non/off-farm work. Sex of household head became a significant and negative determinant of diversification in off/non-farm wage and mixed self-wage employment activities at 5 and 1\% levels of significance, respectively revealing that the male headed households were more able to involves in all off/non-farm employment activities compared to female headed households. The presence of large number of economically active household head has a significant and positive influence on diversification in all the three forms of off/non-farm activities (wage, self and mixed of off-farm and non-farm employment) at 5\% significance level in agreement with a priori expectations. A possible explanation is that households with abundant economically active and working age household head could diversify in non/offfarm employment activities with a view to generate more income by absorbing the available extra labor force from the farm work. Educational level of household head is found to insignificantly and positively affect involvement in non-farm self employment while this variable influences diversification in wage and multiple /mixed self-wage employment opportunities significantly and positively at $1 \%$ significance level.

Attitude to risk of diversifying income determine involvement into off/non-farm wage employment and mixed self-wage activities significantly and positively at 5 and $1 \%$ levels of significance, respectively while its influence on involving in self employment activities is insignificant. Farming experience determines diversification into off/non-farm wage and self employment activities insignificantly but has positive relation and for mixed self-wage activity affects positively at $1 \%$ levels of significance. Family size influence on diversification in off/non-farm wage, and multiple self-wage employment activities is significantly and positively at 10 and $1 \%$ level while negatively for self employment at $10 \%$ level significant. Cultivated land size is appear to determine involvement into off/non-farm wage, self employment and mixed self-wage activities significantly and negatively at $1 \%$ levels of significance. Possibility of irrigated land use at off season influences diversification of off/nonfarm wage employment and mixed self-wage employment negatively and significantly at $5 \%$ and $1 \%$ level of significant respectively while the variable have insignificant effect on self employment. The participation of farm household on cooperative positively and significantly influence off/non-farm wage, self and mixed self-wage employment at $5 \%, 10 \%$ and $1 \%$ level of significant. While willingness to participation of households on off/nonfarm influence significantly and positively to wage, self and mixed self-wage employment at $1 \%$ level of significant. The number of contact/visit by DA's to farm household influences significantly and positively for off/non-farm wage, self and mixed self-wage employment at 5\%,1\%and 1\% level of significant. Distance to the main road, credit service and input/output market center appears to determine diversification into off/non-farm wage, self employment and mixed self-wage activities significantly and negatively at 10,10 and $1 \%$ levels of significance, respectively while distance to credit service influence on involvement in self employment activities is insignificant.

Households with more livestock holding do have the capacity to participate in lucrative off/non-farm employment activities, putting them in a better position than those households with no or small size livestock holding. The insignificant effect of livestock ownership on diversification into self employment could be attributed to the fact that households with no or small livestock holding are pushed towards the less rewarding wage employment activities like the Government rationing programs in which the resource poor households are targeted. The number of crops grown and harvested in quintal per year which can be taken as a proxy for temporal diversification has a statistically significant and negative effect on diversification in off/non-farm self employment and mixed self-wage employment activities at 5\% and 1\% significance level respectively. But this variable appears to be insignificant with regard to off-farm/wage employment activities. The result confirms the argument that farmers who cultivate diverse crops are less likely to involve in off/non-farm activities. A possible explanation is that such farmers devote more of their time to farm operation to sustain their livelihoods. The wealth of household holding significantly and negatively influence diversification in wage employment and positively for selfemployment and mixed self-wage employment activities at $10 \%, 10 \%$ and $1 \%$ level of significance respectively. The marginal effects of each variable on off/non-farm income diversification can be discussed as shown table-3 below.

\subsubsection{Marginal effect of multinomial logit regression results}

The off/non-farm income is calculated as income derived from a certain off/non-farm activity as the result of involvement of the household in to the specific income diversifying activity. Multinomial logit model was applied for the analysis of determinants of off/non-farm activity income using STATA-13 software package and the parameter estimation were done through procedure. Multinomial logit model was applied because of its suitability in identifying the intensity of explanatory variables on off/non-farm wage and self employment incomes of participant households. 
Table-3. Margins, dy dx (age sex edu attrisk fexp fsize lsize tlu irruse coop crdtser poffnon nocont distmr distcrt distmrk wealth totalcp) continuous at means

Conditional marginal effects $\quad$ Number of obs $=200$

Model VCE : Robust

Dy/dx w.r.t.: age sex edu attrisk fexp fsize lsize tlu irruse coop crdtser poffnon nocont distmr distcrt distmrk wealth totalcp

at $:$ age $=40.98($ mean $)$, sex $=1.24($ mean $)$, edu $=.985($ mean $)$, attrisk $=2.45($ mean $)$, fexp $=22.12($ mean $)$, fsize $=5.935$ (mean), lsize $=2.27$ (mean), tlu $=7.46$ (mean), irruse $=.215$ (mean), coop $=.47$ (mean), crdtser $=.26$ (mean), poffnon $=.74$ (mean), nocont $=2.365$ (mean), distmr $=3.83675$ (mean), distcrt=4.68625 (mean), distmrk $=5.3175$ (mean,) wealth $=76773.55$ (mean) and totalcp $=50.265$ (mean).

A. Expression : $\operatorname{Pr}($ offinc $==0)$, predict (), B. Expression $: \operatorname{Pr}($ nonfinc $==0)$, predict ()

$$
\text { C. Expression : } \quad \operatorname{Pr}(\text { bothinc }==0) \text {, predict }()
$$

Delta-method

\begin{tabular}{|c|c|c|c|c|c|c|}
\hline \multirow[t]{2}{*}{ var } & \multicolumn{2}{|c|}{ a. Offinc } & \multicolumn{2}{|c|}{ b. Nonfinc } & \multicolumn{2}{|c|}{$\begin{array}{l}\text { Mixed of off } \\
\text { \&non-farm }\end{array}$} \\
\hline & $\mathrm{dy} / \mathrm{dx}$ & $\mathrm{P}>\underline{\mathrm{Z}}$ & $\mathrm{dy} / \mathrm{dx}$ & $\mathrm{P}>\mathrm{Z}$ & $\mathrm{dy} / \mathrm{dx}$ & $\mathrm{P}>\mathrm{Z}$ \\
\hline Age & 0.009921 & 0.263 & -0.0053653 & $0.079 *$ & $2.21 \mathrm{e}-06$ & $0.000 * * *$ \\
\hline Sex & -0.543199 & $0.011 * *$ & 0.1670263 & 0.332 & 0.0000131 & $0.000 * * *$ \\
\hline Edu & 0.2263726 & $0.006^{* *}$ & 0.1173773 & 0.343 & 0.0000399 & $0.000 * * *$ \\
\hline Attrisk & 0.2187296 & $0.015^{*}$ & 0.1040548 & 0.409 & 0.0000486 & $0.000 * * *$ \\
\hline Fexp & 0.0170155 & 0.314 & 0.0057674 & 0.778 & $2.86 \mathrm{e}-06$ & $0.000 * * *$ \\
\hline Fsize & 0.0547486 & $0.086^{*}$ & -0.1056366 & $0.025 * *$ & $1.37 \mathrm{e}-06$ & $0.000 * * *$ \\
\hline Lsize & -0.3203905 & $0.000 * * *$ & -0.2598557 & $0.015 * *$ & -0.000052 & $0.000 * * *$ \\
\hline Tlu & -0.2683769 & $0.003 * *$ & 0.0870497 & 0.216 & $5.70 \mathrm{e}-06$ & $0.000 * * *$ \\
\hline Irruse & -0.509337 & $0.047 * *$ & -0.0779237 & 0.642 & 0.0000701 & $0.000 * * *$ \\
\hline Coop & 0.6533307 & $0.024 * *$ & 0.2908471 & 0.140 & 0.0001194 & $0.000 * * *$ \\
\hline Crdtser & 0.0951996 & 0.390 & 0.3262005 & $0.033 * *$ & 0.0000218 & $0.000 * * *$ \\
\hline Poffnon & 0.0983026 & $0.000 * * *$ & 0.9826983 & $0.000 * * *$ & 0.0000354 & $0.000 * * *$ \\
\hline Nocont & 0.2724123 & $0.030 * *$ & 0.3131087 & $0.003 * *$ & 0.0001584 & $0.000 * * *$ \\
\hline Distmr & 0.1093302 & $0.073^{*}$ & -0.107527 & $0.061^{*}$ & -0.0000127 & $0.000 * * *$ \\
\hline Distcrt & -0.1355903 & $0.067 *$ & 0.0413495 & 0.573 & 0.000019 & $0.000 * * *$ \\
\hline Distmrk & -0.2449473 & $0.049 * *$ & -0.1307794 & $0.086^{*}$ & -0.0000256 & $0.000 * * *$ \\
\hline Wealth & $-7.24 \mathrm{e}-06$ & $0.048 * *$ & $5.71 \mathrm{e}-06$ & $0.075^{*}$ & $1.36 \mathrm{e}-09$ & $0.000 * * *$ \\
\hline Totalcp & 0.002196 & 0.190 & -0.0017918 & 0.658 & $8.64 \mathrm{e}-07$ & $0.000 * * *$ \\
\hline
\end{tabular}

(*) dy/dx is for discrete change of dummy variable from 0 to 1

Source: Own survey result (2019)

The Multinomial logit model result showed that the variables sex and education of household head, attitude to risk of diversification, family size, size of cultivated land, livestock holding and distances to main road, credit service and market, wealth have statistically significant effects on off-farm employment income while non-farm self employment income was significantly influenced by age, family size, size of cultivated land, cooperative participation, credit service, willingness to diversify income, number of contact by DA's, distance to main road and market, wealth and total crop production in quintal per annual. In agreement to the result obtained in analyzing self employment income, age of the household head is found to be significantly and negatively affecting non -farm self employment income at $10 \%$ level of significance which showed that as age increases, by one unit the intensity of non-farm self employment income decreases by $0.5 \%$ if other variable keep constant (Table -3 above). Thus, the result reveals that younger household heads derived more self employment income compared to their older fellow farmers. The findings of Amare Demissie and Belaineh Legesse (2013) and Bassie Yizengaw (2014) is similar to the result, age is significant determining factor of non-farm self employment income (table-3 above).

Sex of the household head has significantly and negatively affected off-farm wage employment income at 5\% level of significance revealing that male household heads earned more income than the female headed ones. Being female reduces $54 \%$ to diversify into wage employment. Thus the male headed households have obtained better wage employment income because of their ability to access more lucrative off-farm wage employment activities than the female headed households. The attitude to risk of diversification income, of the household had also significantly and positively influence off-farm wage employment income at $10 \%$ significance level but not significant for non-farm self-employment. The positive relationship indicates that as the attitude of household increases to very good, the probability of the household to earn off-farm wage employment income also increases by $21.8 \%$. This could mean that households with good attitude were able to involve in different wage employment activities and earn more income compared to households with weak attitude of income diversification. 
The family size of the household had significant and positive effect on off/non-farm wage and negatively for self employment income at 10\% and 5\% significance level respectively. Though result obtained from multinomial logit analysis hinted that size of family member revealed that, for involvement of households, off/non-farm wage employment income is significantly and positively increases with the size of family member increase. The increases in unit of family size influence to increase to choice by $5.5 \%$ on off-farm wage employment. As the self employment activities are technically demanding and more preferable to active ones, the possibility of their involvement in income diversifying strategies is low. The presence of one unit large number of family members in the household reduce the capacity and ability of household to involve in different income earning activities by $10.6 \%$ such as non-farm self employment. Size of cultivated land operated by the household had significant and negative effect on off/non-farm wage, self and mixed self-wage employment income at 1\% significant level. Though result obtained from multinomial logit analysis hinted that size of cultivated land revealed that, for involving households, off/non-farm wage and self employment income is significantly and negatively influenced by the size of cultivated land. The justification for this finding could be that farmers who cultivate large area of plots have the capacity to produce more and that would enable them to reduce for diversify in off/non-farm wage and self employment. The increases size of cultivated land reduces $32 \%$ to diversify on off-farm wage employment. The result also shows that heads of households with little hectares of land, the probability and willingness to search for self employment may be low as they are pulled towards the more profitable non/off-farm wage employment activities. Hence, having more cultivate land heads of households are mostly pushed to the lending land and selling the product attractive to self employment activities. Keeping other factor constant, for one hectare increase in land to be cultivated, on average the level of diversification among households and overtime decreases by $26 \%$. The result not similar to Bassie Yizengaw (2014), in his study conducted in Ethiopia, reported that there is a positive relationship between the share of rural income generating from off/non-farm income sources and the size of land holding, it was a key factor in determining the income level derived from the more remunerative off/non-farm self employment activities.

Education level of household head was a significant and positive determinant of off-farm wage employment income at 5\% significance level and also has a significant and positive relationship with non-farm self employment income at $10 \%$ level of significance indicating that educated households head were able to generate better income from off/non-farm self employment compared to uneducated house-holds head. An increase education level also $11 \%$ increases diversification to off/non-farm self employment activities. (Table 13) shows the increases educational level increases the choice by $22.6 \%$ to off/non-farm wage income. It is presumed that household heads with formal education are better in their perceptive values, knowledge and decision making ability to diversify into rewarding wage employment activities and earn better income than the illiterate households.

The size of livestock holding measured in TLU per sample household is found to be the significant and negative determinant of off-farm wage employment income and positive for mixed self-wage employment at $5 \%$ and $1 \%$ level of significance respectively. But tlu has positive relationship with insignificant for choice of nonfarm self employment. Households owning large livestock holding have the capacity to accumulate capital and overcome cash constraints for livelihood so, reduces choice and obtain off-farm wage employment income as compared to those households with small or no livestock holding. Irrigation use possibility of land of the household head has a significant and negative relation with off-farm wage and mixed self-wage employment income at $5 \%$ and $1 \%$ level of significance and not significant for choice of non-farm self employment. Indicating that household having available of irrigated land decreases the likelihood of obtaining off-farm wage employment income by $51 \%$ less than households not having irrigated land. Results also show that possibility of participation on cooperative service of households head has significant and positive effect at 5\% and $1 \%$ level of significant for choice of offfarm wage and mixed self-wage employment but not significant for non-farm with having positive relation. Households participate in cooperative could obtain $65 \%$ more off-farm wage employment income compared to those not participate in cooperative. A participation of cooperative service affects to increase diversification by activity. The result also show participation in credit service and willingness to participate on income diversification were also a significant and positive determining factor for non-farm self employment income at $5 \%$ and $1 \%$ level of significance respectively (Table 13). Households who participate more in credit services have high preference to choice and obtain income from non-farm self employment activities as source of cash. A possible explanation an availability of households participation to credit have $32.6 \%$ more chance diversification in to non-farm self employment activities than households not participate to credit service keeping other factor constant. Willingness to participate in diversification was significant at $1 \%$ and $9.8 \%$ more chance of diversifying into off-farm wage employment and $98 \%$ more chance diversification in to non-farm self employment activities with a good willingness compared to households not have willingness to involve.

The effect of number of contact/visit households by DA's has significantly and positively related to off/nonfarm wage, self and mixed self-wage employment income at $10 \%$ and $1 \%$ significance level respectively implying that farmers who are more visited by DA's have more probability of obtaining wage and self employment income as the one unit increase level of contact by DA's also increase possibility of diversification on off/non-farm wage 
self employment by $27 \%$ and $31.3 \%$ in order to ensure food availability for their household from off/non-farm wage and self employment activities respectively keeping other factors constant.

Distance of residence to main road influences off/non-farm wage and self employment income significantly and positively, and negatively respectively at $10 \%$ level of significance. The positive sign, at conventional level of significance, shows that as the distance from homestead to main road increases, the likelihood of the household to earn off-farm wage employment income increases. The implication is that households residing one unit far from main road have increases $11 \%$ and reduce $10.7 \%$ diversification into off/non-farm wage and self employment activities respectively. Distance to market influences off/non-farm wage and self employment income significantly and negatively for off-farm and positively for non-farm at 5\% and $10 \%$ level of significance respectively. The negative sign, at conventional level of significance, shows that as the distance from homestead to market center increases, the likelihood of the household to earn off-farm wage employment income declines. The implication is that households residing one unit far from market centers have less probability to access and reduces $24.5 \%$ of involvement into off-farm wage employment and increase $13 \%$ of involvement into non-farm self employment activities.

\section{Conclusions and Policy Recommendation}

Income from mixed farming (income from livestock and crop income) accounts for the largest sources of income for each group which accounts $86.65 \%$ of the total income. Income from crop production contributed about $58.16 \%$ of the total income while $28.49 \%$ of income is generated from livestock rearing. The importance of off/non-farm income wage and self employment are $3.7 \%$ and $9.6 \%$ respectively among the income activities of households in rural Ethiopia and it accounts $13.3 \%$ of the total income.

Therefore, in an economy where there is rapid population growth associated with declining agricultural land to population ratio, should aim at the economic transformation of rural areas via the establishment and involvement off/non-farm activities as they can reduce unemployment and rural poverty. According to the result of the study, the main determinants of involving in off/non-farm activities are lack of technical skill and knowledge, finance/credit, rural markets and rural infrastructures. Hence, to overcome this important barrier to enter into more remunerative off/non-farm activities, massive efforts are required on the part of government to develop rural infrastructure and financial markets.

The following are the possible areas of intervention which might improve income status and level of income diversification of households.

$>$ Educational level was found to be one of the important determinants the level of household income diversification. The educated peoples diversify their income through opting for salaried jobs, self-employment activities, etc., illiterate persons engage themselves in agricultural activities which are mostly valuable to weather and other damage and partially in wage employment. Therefore, investing in education and increasing access of primary up to secondary education will help the rural households in getting alternative income.

$>$ Household's family size had negative impact on the household's level of income diversification (non-farm self employment). The family planning program should be further focus on and more awareness should be created among the rural farmers on the need to reduce their family size for improvement in households' welfare. Proper attention should be given to limit the increasing population. This could be achieved by proper awareness creation about practicing family planning.

$>$ Livestock ownership had positive significant impact on the level of income diversification. Moreover, Farm households with larger livestock holdings are more food secured than farmers with less livestock holdings. Therefore, farmers should be encouraged to engage in livestock husbandry through providing with improved livestock production technologies (health service, improved breeds and feeds) to improve production and productivity of the sector, this will ultimately increase diversification choice and livelihood status.

$>$ Frequency of extension contact was found to affect the supply of on farm product to the market positively and significantly as well as the importance and ways of diversifying income, so Woreda office of rural development shall work more on increasing the frequency of extension contact to improve the awareness of farmer producers about the use of income diversification and increase production, income and improve the livelihoods of farm households.

$>$ The result shows that age of household, attitude to risk of income diversification and farming experience were found to affect the diversification of farm households on different income strategies (off/non-farm), which indicates farmers who are middle aged and experienced which have good attitude was relatively higher involvement than those who are aged and weak attitude to diversify. Therefore, intervention from the side of the government and responsible are required to educate and aware farmers who are weak attitude and less experienced create access to transform into active participation to help farmers easily diversify their income and reduce risk occurrences.

$>$ The government shall make access to modern credit to provide facilities and equipment to improve the production and supply of quality farm product by small holder farmers to the local and international 
markets.

$>$ The government as well as the responsible one shall make access to cooperative unions and awareness of participation in order to simplify as well as easily provide facilities and input/output equipments to improve the production and supply of quality farm product by small holder farmers to the local and international markets.

$>$ Generally the study revealed that having income generating activity apart from agriculture, the potential to increase income. Therefore, it is important to encourage farm households to have income outside agricultural income since agricultural income is vulnerable to different shocks. Policy makers should look for means of improving these activities and make policies that will promote them without having negative effects on farming based on the relation between income diversification and total household income.

\section{References}

Bassie Yizengaw (2014). Determinants of Household Income Diversification and Its Effect on Food Security Status in Rural Ethiopia: Evidence from Ethiopia Longitudinal Rural Household Survey, Addis Ababa University, Addis Ababa, Ethiopia.

Bekelu T. And Abdi-Khalil E.,(2013). Determinants and Patterns of Income Diversification among Smallholder Farmers in Akaki District, Ethiopia. Journal of Research in Economics and International Finance (JREIF) (ISSN: 2315-5671) Vol. 2(4) pp. 68-78, April, 2013.

Benjamin, D. Katia, C. Aminata, C.Stefania, D. (2013).Household income generating activities in developing countries, World Bank development Report.

Berhanu Adenew. (2006). Effective Aid for Small Farmers in Sub-Saharan Africa: Southern Civil Society Perspectives; Canadian Food Security Policy Group, Addis Ababa.

Berhanu Adenew. (2006). Effective Aid for Small Farmers in Sub-Saharan Africa: Southern Civil Society Perspectives; Canadian Food Security Policy Group, Addis Ababa.

Dimova R. and Sen K.(2010). Is household income diversification a means of survival or a means of accumulation? Panel data evidence from Tanzania. The University of Manchester brooks world poverty institute.ISBN:978$1-907247-21-7$.

Demissie A. And Legesse, B. (2013). Determinants of income diversification among rural households: The case of smallholder farmers in Fedis district, Eastern hararghe zone, Ethiopia. Journal of Development and Agricultural Economics Vol. 5(3), pp. 120-128

Ellis F. (1998). Household Strategies and Rural Livelihood Diversification, the Journal of Development Studies, Vol.35, No.1, pp.1-38.

Ellis F. (2000). The Determinants of Rural Livelihood Diversification in Developing Countries", Journal of Agricultural Economics, Vol. 51(2): 289-302.

Ellis, F., and Biggs, S. (2001). Evolving Themes in Rural Development 1950s-2000s. Development Policy Review, 19(4):437- 448.

Green, H.W., (2003). Econometric Analysis: Fourth Edition. New York University Macmillan Publishing Company. Implications for development interventions Master thesis.

Gujarati, D., (1998).Essentials of Econometrics. Irwin McGraw-Hill Book Co. Singapore.

Haggblade, S., Hazell, P., and Reardon, T. (2002). Strategies for Stimulating Poverty-Alleviating Growth in the Rural Nonfarm Economy in Developing Countries. EPTD Discussion Paper No. 92, pp 126.

Holden, Stein, Bekele Shiferaw, and John Pender. 2004. Non-farm income, household welfare, and sustainable land management in a less-favoured area in the Ethiopian Highlands. Food Policy, 29, 369-392.

Hosmer, D. W., Jr., S. A. Lemeshow, and R. X. Sturdivant. 2013. Applied Logistic Regression. 3rd ed. Hoboken, NJ: Wiley.

Lemi, A. (2006). The Dynamics of Income Diversification in Ethiopia: Evidence from Panel Data", Working Papers 3. University of Massachusetts, Boston.

Maitra, P. (2001). "Are the Poor more Vulnerable to Income Shocks? An analysis of Consumption Insurance in Rural India," Preliminary version.

MoFED (Ministry of Finance and Economic Development) (2002). Ethiopia: Sustainable development and poverty reduction program. pp. 34, $71 \& 76$. Federal Democratic Republic of Ethiopia (FDRE) Ministry of Finance and Economic Development (MoFED), Addis Ababa, Ethiopia.

Mulat Demeke (2001). Off-farm Income Generation in Ethiopia: Opportunities and Constraints in Food- insecure Woredas of Oromiya and Amhara Regional States. Ethiopian Development Forum, vol 2. No 1.

Raju G (2014). Factors Affecting Nonfarm Income Diversification among Rural Farm Households in Central Nepal. Int. J. Agric. Manage. Dev. 4:2.

Woldenhanna, T., and Oskam, A. (2001). Income Diversification and Entry Barriers: Evidence from the Tigray Region of Northern Ethiopia. Food Policy, 26(4):351-365.

Yishak Gecho (2017). Rural Farm Households' Income Diversification: The Case of Wolaita Zone, Southern 
Ethiopia. Social Sciences. Vol. 6, No. 2, 2017, pp. 45-56.doi: 10.11648/j.ss.20170602.12.

Zerai, B. and Gebreegziabhe, z., (2011). Effect of Nonfarm Income on Household Food Security in Eastern Tigray, Ethiopia: An Entitlement Approach. Food Science and Quality Management, Vol 1. 